\title{
The Evaluation of Online and Face to Face Physical Education Learning Policy at Elementary School Level
}

Ach. Baidowi

STAI Publisistik Thawalib Jakarta, Indonesia

\begin{tabular}{l}
\hline Article Info \\
\hline Article History: \\
Received : September 2020 \\
Accepted : September 2020 \\
Available Online : October 2020 \\
Keywords: \\
educational policy, face to face learn- \\
ing, online learning, physical educa- \\
tion \\
\hline
\end{tabular}

\begin{abstract}
The wide spread of Covid-19 virus in Indonesia enforced the temporary closure of education process followed by the remote learning regulation for all levels of education. The aim of the study was to evaluate the process of online and face to face learning by using the evaluation stage from Edward A. Schuman through a qualitative approach. The data were collected by conducting observation, documentation, and interview of four Physical Education, Sport, and Health teachers, students grade 4-6, classroom teachers, and parents. The results of the study showed that (1) the purpose was to prevent the spread of Covid-19 virus and to provide a maximum education service. (2) The problems faced in the face to face learning included the lack of tools, time constraint, the lack of practice, the unreachable goals, and the lack of supervision. Meanwhile, the problems faced in the online learning included the lack of media, the lack of signal, no practice was conducted, and the teachers did not use the method. (3) The activities in a face to face learning included visiting students' houses, while the activities in online learning included using a smartphone and social media. (4) The changes included accessing a wide material, understanding IT, lack of motivation, lack of enthusiasm, the decrease in understanding, and the high use of lecturing method. (5) The changes occurred as the result of the online and face to face learning processes. The results conclude that, based on the problems faced and negative changes perceived by students and teachers, the online and face to face learning regulation is less effective to be conducted for a long period of time. The implication of this study was for the betterment of the instructional process and educational policy.
\end{abstract}




\section{INTRODUCTION}

Teachers play a role as facilitator in the instructional process, thus the teachers with their expertise and professionalism are expected to involve the students in the quality teaching learning process that could bring the students to achieve a maximum learning outcome and suitable with the objective of the instruction (Buchari, 2018). During the Covid-19 pandemic, due to the rapid spread of the virus, the activities in various sectors, including education sector, are temporary closed by the government as an effort to prevent the Covid-19 virus spread, thus the instruction at schools cannot be administered for a while. However, the challenges and problems araised specially in the Physical Education, Sport, and Health subject as the practical instruction should be carried out in the field or a special space for sport activities. The online learning creates a gap in teaching media, the lack in facilities, to the regulation change about education due to the rapid information and technology development requiring the evaluation and renewal in the educational policy. The obstacles during the instructional process include the lack of principal leading style, the lack of educational tools, the low qualification of teachers, the lack in the student characteristics, the uncertain educational curriculum or instructional curriculum, and the social and economy factors that directly and indirectly affect the educational process, especially the instructional process (Komalasari, 2010).

This study was aimed at explaining and describing the face to face learning and online learning of Physical Education, Sport, and Health subject and the impacts of the instruction on the student achievement or learning outcomes through the evaluation of face to face and online learning regulation evaluation research by using an evaluation approach from Edward A. Schuman. The evaluation on the educational policy was conducted to find out the cause of the implementation of a regulation and the effect from the implemented educational regulation, thus the advantage gained by the target or the policy maker from the implementation of the educational regulation can be discovered (Arwildayanto, Suking, \& Sumar, 2018).

\section{METHOD}

This research used a qualitative approach, a research conducted to gain a natural or real data where the result of the research is explained or described in brief words or sentences (Sugiyono,
2018). The data collection was administered in Sampang District. The data collection techniques used were interview, documentation, and observation. The face to face interview was conducted based on the availability of the respondents. The indirect interview was conducted by utilizing WhatsApp to support and complete the result of the interview which was directly conducted. The purpose of this technique was to deeply find out real statements and opinions of the respondents related to the face to face and online learnings.

The interview was administered in two languages, adjusted with the condition of the respondents, including Madura language for the students and parents to gain a deep and real result of the interview and Indonesia language for the Physical Education, Sport, and Health teachers and teachers of other subjects. The interview was carried out to: (1) 4 Physical Education, Sport, and Health teachers, 2 teachers from rural area and 2 teachers from urban area; (2) students in each location of research, especially from grade 4, 5, and 6; (3) students and parents; (4) classroom teacher (teachers from other subjects) as the support for the research data result. The guideline of the interview data collection technique shows in Table 1.

The observation techniques were conducted by seeing and evaluating the face to face and online Physical Education, Sport, and Health learning activities. Besides for evaluating purpose, the observation was conducted to find out the perception of the teachers, students, and society about the face to face and online instructions. The guideline of the observation as shown in Table 2.

Table 2. Observation Guideline

\begin{tabular}{ll}
\hline Observation Technique & \multicolumn{1}{c}{ Observation Object } \\
\hline $\begin{array}{l}\text { Face to Face Physical } \\
\text { Education, Sport, and } \\
\text { Health Learning }\end{array}$ & $\begin{array}{l}\text { Observing the face to face } \\
\text { learning process related to } \\
\text { the process, media or } \\
\text { tools, place, and respons- } \\
\text { es (behaviors) of the soci- } \\
\text { ety on the face to face } \\
\text { learning, and so on. }\end{array}$ \\
\hline Online Physical Educa- & $\begin{array}{l}\text { Observing the online } \\
\text { learning process related to } \\
\text { tion, Sport, and Health } \\
\text { Learning }\end{array}$ \\
& $\begin{array}{l}\text { the process, media or } \\
\text { tolivered to the students, } \\
\text { delive the teacher } \\
\text { place, and so on. }\end{array}$ \\
\hline
\end{tabular}


Third documentation is collecting documentation data of face to face and online learning such as photograph of Physical Education, Sport, and Health subject activities, the lesson plan of face to face and online learning of Physical Education, Sport, and Health teachers, and other documentations supporting the result of the study. The guideline of the observation technique is as shown in Table 3.

Table 3. Documentation Guideline

\begin{tabular}{lc}
\hline Documentation Topic & Documentation Type \\
\hline Lesson Plan and Sylla- & Files \\
bus of face to face and & \\
online instructions & \\
\hline Photograph of the face & Photograph \\
to face and online in- & \\
structional process & \\
\hline
\end{tabular}

To validate the data of the research, firstly, the triangulating the sources, including comparing data of the result of the study from one informant to other sources, was conducted. Secondly, the triangulation technique, by comparing the result of the interview with the results of documentation and observation, was administered. Triangulation was conducted by combining various sources, data collection technique, and data collection time (Sugiyono, 2015). The analysis of the research data was conducted in some stages, first stage was data condensa- tion by selecting the result of the study data that were suitable with the focus of the study. Secondly, presenting the data of the research in brief sentences supported by figures and tables to clarify the content and support the readers. The third stage was creating or formulating conclusion of the result of the study data.

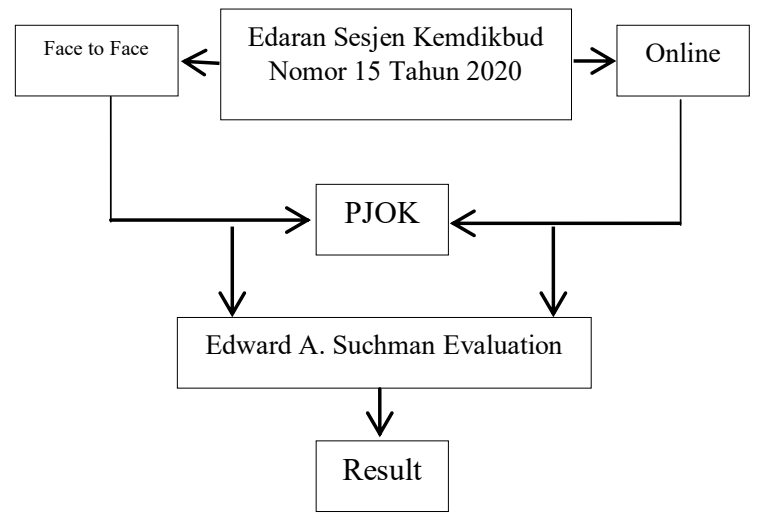

Figure 1. Research Design

\section{Result and Discussion}

This research employed a policy evaluation approach from Edward A. Schuman (Arwildayanto, et al., 2018) that can be seen in Figure 2. From the policy evaluation stages above, the results of the research about the implementation of face to face and online learning regulation of Physical Education, Sport, and Health subject in the elementary

Table 1. Interview Guideline

\begin{tabular}{|c|c|c|}
\hline Aspect & Indicator & Respondent \\
\hline $\begin{array}{l}\text { Identification of } \mathrm{Ob}- \\
\text { jectives }\end{array}$ & $\begin{array}{l}\text { Able to explain the objective of the face to face learning } \\
\text { Able to explain the reason of face to face learning } \\
\text { Able to explain the objective of online learning } \\
\text { Able to explain the reason of online learning }\end{array}$ & $\begin{array}{l}\text { PE Teachers } \\
\text { Classroom } \\
\text { Teachers }\end{array}$ \\
\hline Analysis of Problems & $\begin{array}{l}\text { Able to explain the problem or obstacle faced by Physical Education, Sport, and } \\
\text { Health teachers in conducting the face to face learning } \\
\text { Able to explain the problem or obstacle faced by Physical Education, Sport, and } \\
\text { Health teachers in conducting online learning } \\
\text { Able to explain the problem or obstacle faced by students in online Physical } \\
\text { Education, Sport, and Health subject } \\
\text { Able to explain the problem or obstacle faced by students in the face to face } \\
\text { Physical Education, Sport, and Health subject } \\
\text { Able to explain the problem or obstacle faced by parents in the student online } \\
\text { learning } \\
\text { Able to explain the problem or obstacle faced by parents in the student face to } \\
\text { face learning }\end{array}$ & $\begin{array}{l}\text { PE Teachers } \\
\text { Classroom } \\
\quad \text { Teachers } \\
\text { Students } \\
\text { Parents }\end{array}$ \\
\hline $\begin{array}{l}\text { Description and } \\
\text { Standardization }\end{array}$ & $\begin{array}{l}\text { Able to explain the description and standardization of the face to face Physical } \\
\text { Education, Sport, and Health learning } \\
\text { Able to explain the description and standardization of the online Physical Edu- } \\
\text { cation, Sport, and Health learning }\end{array}$ & PE Teachers \\
\hline $\begin{array}{l}\text { Measurement of the } \\
\text { Changes Occurred }\end{array}$ & $\begin{array}{l}\text { Able to mention the indicators or the change characteristics occurred in both } \\
\text { online and face to face Physical Education, Sport, and Health instructions }\end{array}$ & $\begin{array}{l}\text { PE Teachers } \\
\text { Students }\end{array}$ \\
\hline $\begin{array}{l}\text { The decision of The } \\
\text { Effect of The Changes }\end{array}$ & $\begin{array}{l}\text { Able to explain the cause of the changes on the face to face and online Physical } \\
\text { Education, Sport, and Health instructions }\end{array}$ & PE Teachers \\
\hline
\end{tabular}


school level in Sampang District, in general, are depicted in the Table 4.

\section{Identification of Policy Objectives}

The result of interview found that: the objectives of the face to face and online learnings were, first, for the health and safety of teachers and students by preventing the spread of Covid-19 virus. The result of interview found that face to face learning was conducted directly with the students where the time and the number of students were limited in order to prevent the spread of the Covid-19 virus. The face to face learning by the Physical Education, Sport, and Health teachers had been conducted based on the health protocols suggested by government by visiting the students' residences equipped by face mask and keeping the distance. Before the Physical Education, Sport, and Health instruction was conducted, the students were suggested to wash their hands with soap. When the instruction started, the students did some physical fitness movements so that they could implement the movement every day

Table 4. Matrix and Results of The Study

\begin{tabular}{|c|c|c|}
\hline Evaluation Stage & Result & Respondent \\
\hline \multirow[t]{2}{*}{$\begin{array}{l}\text { Identification of Objec- } \\
\text { tives } \\
\end{array}$} & Health and safety of teachers and students (using health protocols) & PE and Classroom Teachers \\
\hline & Giving maximum educational service to the students & PE and Classroom Teachers \\
\hline \multirow[t]{20}{*}{ Analysis of Problems } & Face to Face & \\
\hline & Insufficient facilities & PE Teachers and Students \\
\hline & Lack of focus during learning & PE Teachers and Students \\
\hline & Conflict with other residents & PE Teachers, Students, and Parents \\
\hline & Small number of materials & PE Teachers and Students \\
\hline & The practice was not maximum & PE Teachers and Students \\
\hline & Limited time & PE Teachers and Students \\
\hline & Small number of delivered competence and objective of learning & PE Teachers \\
\hline & $\begin{array}{l}\text { Some teachers used only face to face learning and did not use the online } \\
\text { learning }\end{array}$ & PE and Classroom Teachers \\
\hline & $\begin{array}{l}\text { The lack of supervision and evaluation process of Physical Education, } \\
\text { Sport, and Health instruction from the principals and other educa- } \\
\text { tional supervisors }\end{array}$ & PE and Classroom Teachers \\
\hline & Online & \\
\hline & Connection Problem & PE Teachers and Students \\
\hline & Do not have media for online learning & PE Teachers, Students, and Parents \\
\hline & Do not have internet services & PE Teachers, Students, and Parents \\
\hline & Neglecting the task (tends to leave the task) & PE Teachers and Students \\
\hline & The lack of parents and students understanding of the gadget & PE Teachers, Students, and Parents \\
\hline & $\begin{array}{l}\text { Cannot practicing the Physical Education, Sport, and Health materials, } \\
\text { giving written task only }\end{array}$ & PE Teachers and Students \\
\hline & $\begin{array}{l}\text { Some teachers did not use online method due to the limited connection } \\
\text { and the students did not have the media (rural) }\end{array}$ & PE and Classroom Teachers \\
\hline & $\begin{array}{l}\text { The supervision was conducted to observe the material and task delivery } \\
\text { to the students }\end{array}$ & PE and Classroom Teachers \\
\hline & $\begin{array}{l}\text { Evaluation was conducted to examine the relevance of the material and } \\
\text { lesson plans }\end{array}$ & PE and Classroom Teachers \\
\hline \multirow{5}{*}{$\begin{array}{l}\text { Description and Stand- } \\
\text { ardization } \\
\end{array}$} & Face to Face & \\
\hline & Visiting students for online learning evaluation & PE and Classroom Teachers \\
\hline & Visiting the students to give thematic materials & PE and Classroom Teachers \\
\hline & Online & \\
\hline & $\begin{array}{l}\text { Conducted by using smart phone and social media to give the written } \\
\text { materials and tasks }\end{array}$ & PE and Classroom Teachers \\
\hline \multirow{7}{*}{$\begin{array}{l}\text { Measurement of Oc- } \\
\text { curred Changes }\end{array}$} & Can access the material widely & PE and Classroom Teachers \\
\hline & $\begin{array}{l}\text { Teachers and students could understand and utilize information and tech- } \\
\text { nology }\end{array}$ & PE and Classroom Teachers \\
\hline & The student motivation decreased & PE Teachers and Students \\
\hline & The student enthusiasm decreased & PE Teachers and Students \\
\hline & The material comprehension decreased & PE and Classroom Teachers \\
\hline & The student achievement (student learning outcomes) decreased & PE and Classroom Teachers \\
\hline & The higher use of lecturing method & PE Teachers and Students \\
\hline $\begin{array}{l}\text { Decision of The Effect } \\
\text { of Changes }\end{array}$ & $\begin{array}{l}\text { The changes occurred due to the less effective face to face and online } \\
\text { learning for Physical Education, Sport, and Health subject }\end{array}$ & PE and Classroom Teachers \\
\hline
\end{tabular}


at home to maintain their health. The teachers were expected to administer the instructional process that enabled students to achieve their learning objectives and created interaction between teachers and students. The teachers should not only deliver knowledge, but also other values and create a fun learning atmosphere to improve the students' learning outcomes (Suwardi, 2018).

From the result of interview, it was found that Physical Education, Sport, and Health teachers had conducted a maximum face to face and online learnings according to the thematic materials and the decided time of the face to face and online learning by utilizing the provided learning facilities although it was not sufficient. All the efforts were carried out to achieve a good Physical Education, Sport, and Health educational service so that the objective of the Physical Education, Sport, and Health instruction could be delivered maximally during the Covid-19 pandemic. Teachers, as the professionals, had a responsibility to build the interest, talent, and achievement of the students so that the students could achieve a life skill that will be beneficial for their life (Musa, 2015).

\section{Analysis of the Problems}

The problem found in the face to face and online learnings of the Physical Education, Sport, and Health subject is described as follows: Face to face (1) The facilities were insufficient. The Physical Education, Sport, and Health learning, that is identical with the material and practice delivery, had some obstacles in the face to face learning, including: first the result of the interview and observation found that the facilities of the Physical Education, Sport, and Health instruction were insufficient and the teachers utilized the facilities provided in the place of learning. It made the Physical Education, Sport, and Health instruction take a lot of time in the process. The Physical Education, Sport, and Health instruction at school had been provided with the learning tools and media, but for a face to face learning, teachers and students were still required to search for suitable tools and media for the Physical Education, Sport, and Health material given. For example, for football material, teachers and students, should look for the ball from the surrounding and the place for practicing the material was not available. The tools used and utilized by teachers to support the teaching learning process in class or outside the class in an instruction named learning media (Mulyasa, dalam Nasrudin \& Maryadi, 2018).

The findings during the interview regarding the face to face learning showed that (1) The student understanding of the Physical Education, Sport, and Health material decreased. For example, in football material, namely how to kick a ball, the teacher only explained how to kick without practicing because of inadequate facilities and infrastructure (Barnawi \& Arifin, 2012). (2) Students did not focus on learning while they were in the home environment, because they were disturbed by their siblings or family members and the presence of residents watching the learning process, so that the focus of teachers and students on the learning process was not optimal or disturbed. (3) There were some residents who feel uncomfortable and disturbed by the existence of the face to face learning process because the learning was quite disturbing for residents who were active or doing work that could not be left behind, so they tended to have a conversation with the teacher and asked the teacher to move the learning process to another place. However, focus and concentration that involve students' psychological, motor, and cognitive processes in the learning process are the main factors so that the goals and learning process can be achieved and carried out well (Ikawati, 2015). (4) Limited face to face learning time, it affects the teachers in providing the material. For example, football material that should be given in two or three meetings, in the new face to face learning could be completed in a month or even more. (5) The Physical Education, Sport, and Health learning conducted through a practical approach, in the face to face learning, could not run optimally because the facilities and infrastructure in the surrounding environment were inadequate and the number of students was limited so that the practice of The Physical Education, Sport, and Health was carried out inadequately and only delivered the basic material. With the right media or tools for the learning material, the learning process can run in an interesting and fun way so that it has an impact on the student learning performance (Supriyo, 2015). (6) The limited time had a significant negative effect on The Physical Education, Sport, and Health learning, resulting in a lack of student understanding of the material being taught. The amount of time in the teaching and learning process of The Physical Education, Sport, and Health is very important, because The Physical Education, Sport, and Health is a subject related to 
FITT (Frequency, Intensity, Time, Type) which determines the success of The Physical Education, Sport, and Health learning (Sugiarto, 2015). (7) Only a few competencies and learning objectives were achieved. Due to the limited time, tools or media, and the number of students, the competence and objectives of the Physical Education, Sport, and Health learning process was not maximally delivered. This clearly related to The Physical Education, Sport, and Health lesson, which is focused on maximizing the competence and potential of students in the world of sports, and can hinder the development of students who have more potential in the sports field (Fikri, 2018). (8) The Physical Education, Sport, and Health teachers in rural areas preferred and maximized the face to face learning process and did not use online methods. It was due to the lack of internet access in rural schools and most students did not have the tools or media to do online learning. In addition, the face to face method was considered to be much more effective for The Physical Education, Sport, and Health lessons, because, even though the number of students and time was limited, teachers could still provide materials and practice it in front of students with the existing facilities and media. The teaching technique used by the teacher is the teacher's way of achieving the goals and targets of the learning process or education for students (Lutan, in Yulianti, 2016). (9) Face to face learning, that was carried out outside the school environment, resulted in a less supervision and evaluation on the learning process from the principal. It had an indirect impact on the quality of the learning process which could not be measured in real terms by the principal. An assessment of the teaching and learning process is critical to be done by a school principal. Because by carrying out the assessment, the principal can see the advantages and disadvantages of the performance of their subordinates, namely the teacher, thus, according to the results of the assessment, the principal can provide a guidance and input for a better teacher performance (Rismawan, 2015).

The problems that occurred in the online learning process are as follows: (1) Online learning required teachers and students to be able to access the internet to support the online learning process. The slow and insufficient networks resulted in the stagnation of the online learning process in rural areas. Teachers could not deliver materials and students could not access materials provided by the teacher. It made the communication between teach- ers and students in the online learning process did not run well (Aziz, 2017). (2) Most elementary students were not allowed to use and own gadgets by their parents, while some of the students did not have gadgets due to the economic factors of the students' parents, this resulted in the unevenly online learning process among students. (Wisman, 2017). (3) Online learning that used the internet as its main support required parents of students to buy internet quota (internet services). Parents with low economics condition preferred not to buy internet quota to support the online learning process, they preferred to wait for the teachers to do a face to face learning. Some parents with a high social and economic status did not have difficulties in fulfilling their children psychological and physical needs (Karim, in Muhammad, Ali, \& Arifin, 2017). (4) Elementary students had not learnt ICT subjects. It had impacts on the lack of the student understanding of IT, as well as parents of students who were mostly from rural schools. They could not use IT so that the online learning process could not run well, especially for students who could not use and utilize IT. (5) Because of the student inability in using and utilizing IT, especially gadget, the online assignments tended to be ignored and even neglected by elementary school students. Problems occurred due to the internal student factors include intelligence, willingness, motivation, and so on. Meanwhile, external causes include the environment, the socioeconomic conditions of parents, and the school environment (Darimi, 2016). (6) Online learning that was carried out online was administered because teachers and students could not do face-to-face learning and could not practice learning directly. The teacher could only provide written materials or assignments to students, such as the task of drawing a soccer field, describing the meaning of run, and so on. (7) There were teachers who did not use online methods because of network limitations and students did not have the media, thus the learning process only maximized the face to face learning method so that students could understand the Physical Education material and it was considered more effective by some teachers because they could explain the material directly to students. Developing movement skills of the students, mastering various games in the field of sports, and maintaining the student physical and spiritual fitness are the goals of Physical Education, Sport, and Health at schools (Kristiyandaru, in Junaedi \& Wisnu, 2016). (8) The supervision of online learning from the principal was carried out only to see the 
process of giving material or assignments to students by asking the teachers. Meanwhile, the evaluation of the principal was carried out by asking whether the material presented was in accordance with the meeting time in the lesson plan. The clinical supervision of teachers could be done by listening to teacher statements, providing motivations and inputs as the reinforcement for subsequent learning activities, as well as searching and solving various problems that often occurred in the learning process (Nurcholiq, 2017).

\section{Description and Standardization of Face to Face Activities}

The weakness and strength of the online and face to face learning are presented in Table 5. Face to face learning was carried out by visiting students' houses, asking about the learning situation of Physical Education, Sport, and Health subject. The face to face learning process was carried out by following the health protocol to prevent the spread of the Covid-19 virus, where learning was started by doing activities for body fitness, then evaluated the material or assignments in the online learning process, assessed student assignments, and exemplified movements in online material. This kind of management is believed more effective and efficient (Sunaryo, in Sunhaji, 2014). After the habituation of activities and health protocols, students received a
The online learning process was carried out by using IT devices, such as smart phones, and social media, such as Wahtsapp, to communicate with the students. The teacher created a group on WhatsApp social media to make the coordination with the parents and students easier and to facilitate the delivery of information related to the material being taught and tasks that must be done according to the submission time set by the teacher. One of the approaches in managing the class is the power approach, where the class is managed by controlling the student behavior so that an orderly and disciplined classroom situation is created (Sunaryo, in Sunhaji, 2014).

\section{The Level of Change Measurement}

The face to face and online learning processes, directly and indirectly, affected the Physical Education, Sport, and Health instruction. The effects are both negative and positive. The data are shown in Table 6. Table 6 describes the positive changes of online and face to face learnings. (1) A positive change during online and face to face learning was that teachers and students could access materials widely through the use of IT tools. Teachers and students who previously lacked or were unable to use and utilize IT, they eventually could use and utilize IT to support the process and activities of learning to teach both online and face to face learnings (Sudrajat, in Khodijah \& Nurizzati, 2018). (2)

Table 5. Strengths and Weaknesses

\begin{tabular}{|c|c|c|}
\hline Learning & Strength & Weaknesses \\
\hline $\begin{array}{l}\text { Face to } \\
\text { Face }\end{array}$ & $\begin{array}{l}\text { Able to directly give } \\
\text { the material and prac- } \\
\text { tice }\end{array}$ & $\begin{array}{l}\text { The material was not delivered fully } \\
\text { The high use of lecture method (not suitable for Physical Education, } \\
\text { Sport, and Health subject) } \\
\text { Distracted learning process } \\
\text { The facilities and media for learning were not sufficient } \\
\text { The supervision of learning process from the principal was lacking }\end{array}$ \\
\hline Online & $\begin{array}{l}\text { Able to access the ma- } \\
\text { terial widely for the } \\
\text { teachers } \\
\text { Flexible time }\end{array}$ & $\begin{array}{l}\text { The material understanding decreased (due to the absent of direct } \\
\text { explanation from the teachers) } \\
\text { The direct interaction between teachers and students decreased } \\
\text { The supervision from the principal was only about the material deliv- } \\
\text { ery completion to the students }\end{array}$ \\
\hline
\end{tabular}

thematic material. The learning process was carried out properly and maximally according to the predetermined time. The teaching and learning process is an effort made by the teacher in stimulating, fostering, and motivating students so that an educational process occurs, called the learning process in the classroom (Chauhan, in Sunhaji, 2014)
Negative changes included the decrease of the student motivation and enthusiasm for learning. It was because the learning process was carried out with insufficient media, limited equipment, limited time and limited material so that students often underestimated the lessons that would be given and chose not to take lessons (both online and face to face learnings) (Romadhoni, Wiharna, \& Mubarak, 2019). A 
distant learning, the limited number of face-to-face hours, and limited materials made it difficult for students to understand the Physical Education material that should be combined with practices. This directly affected the student learning outcomes, that were lacking, because a direct guidance and explanation from the teacher about the material being taught was lacking. Psychological factors that affected the student learning performance were the intelligence, student attitudes, student interests and talents, using two approaches, namely direct oral lectures conducted in the face to face learning, and indirect lectures used in online processes. Learning that is often carried out orally made students feel bored, on the contrary, if learning is carried out by using and utilizing tools or props to help clarifying the material or concept given, it has an impact on the feeling of joy of the students during following the lessons (Rosyada in Fakhrurrazi, 2018) .

Table 6. Positive and Negative Changes

\begin{tabular}{|c|l|}
\hline \multicolumn{1}{|c|}{ Positive } & \multicolumn{1}{c|}{ Negative } \\
\hline $\begin{array}{l}\text { Teacher and student could access the mate- } \\
\text { rials widely }\end{array}$ & The student learning motivation decreased \\
$\begin{array}{l}\text { The teachers and students, who previously } \\
\text { were lack of IT understanding, could } \\
\text { understand and utilize IT }\end{array}$ & $\begin{array}{l}\text { The student learning enthusiasm decreased } \\
\text { The student achievement and learning outcomes decreased } \\
\text { The students who were unable utilizing IT missed the materials } \\
\text { The high use of lecture method, which is not suitable for the } \\
\text { Physical Education, Sport, and Health subject }\end{array}$ \\
\hline
\end{tabular}

habits shown by students, enthusiasm, motivation, and so on. While external factors that influenced them were the family environment and the school environment where the learning was conducted (Ahmadi \& Supriyono, in Syafi'i, Marfiyanto, \& Rodiyah, 2018). (3) Students, who had not been able to utilize IT, missed the subject matter. There was a statement from a teacher who said "as a result of the condition of learning, smart students are getting smarter, while low achieving students are becoming left behind." It was proven that, for students who were able to make good use of IT, they could quickly access and find the material being taught. Meanwhile, students who could not use IT properly would miss the material that the teacher had given. It had an impact on the student achievement (learning outcomes) which was not evenly distributed. This condition made it difficult for Physical Education teachers in completing the material being taught. An effective learning is a teaching and learning process that can provide understanding of theory, support student to be clever and diligent in learning something, provide quality opportunities and services to learn, and change student behaviors so that they can apply their knowledge in a real life (Djiwandono, in Fakhrurrazi, 2018). (4) Different teaching methods. Physical Education, Sport, and Health lesson is identical with the mixed methods between lectures and demonstrations (practicing). In the Learn from Home learning process, the Physical Education, Sport, and Health learning method used more lectures and less practices. Lectures were conducted by

\section{The Observed Changes}

The negative changes from the face to face and online learning system include decreasing the student motivation and enthusiasm, decreasing the student understanding of theory and achievement, using more lecture methods, and only learning theoretically with a minimal practice. It proves that the face to face and online learning method system in Physical Education, Sport, and Health subject is less effective to be applied for a long time. It is because, firstly, Physical Education, Sport, and Health subject must be carried out in a balanced combination of theory and practice. Secondly, the students who have potential in the field of sports might not be able to maximally develop their potential. Developing and guiding the potential, abilities, interests, and talents of students in the field of sports are facilitated through the Physical Education administered in the intra curricular or extracurricular programs at schools (Fikri, 2018).

\section{CONCLUSION}

The face to face and online learning system in the Physical Education, Sport, and Health subject at the elementary school level was less effective to be administered in a long time. This was because, first, there were still many students who had not been able to use and utilize IT properly. Second, the students' motivation and enthusiasm were reduced due to the distracted learning process, inadequate facilities and media, and a high use of lecture teaching methods that created boredom. Third, students' 
understanding and learning outcomes were reduced because the material and learning objectives were not fully conveyed. Fourth, the direct supervision of student learning outcomes from teachers was lacking due to limited face-to-face hours between teachers and students. Also, the supervision from the principal on the teacher learning process tended to be absent or not implemented.

Suggestions that can be given are as follows: for online learning: to prepare students for online or other distance learning, it is better if ICT subject is added in the elementary school, especially in upper classes, including grade 4,5 , and 6 . The goal is, besides adding and developing potential and student competence in the field of ICT, to enable students in using and utilizing IT tools for learning purposes and so on. Face to face learning: it is better if the Physical Education, Sport, and Health teacher can prepare and bring supporting equipment for the face to face learning from school or their own creativity. Other researchers: it is better if other researchers conduct a research about distance learning methods that are effective and efficient for elementary school students. The results of the research are expected to have a positive impact and become a guideline for elementary school teachers who use face to face or online learning approaches.

The implications of the results of this study are that, first, the results can be used as the input and knowledge for schools, especially Physical Education, Sport, and Health teachers in carrying out the learning process in both face to face and online learning processes. The second is that the results are expected to be used as the input and material for government consideration in formulating educational policies, especially policies regarding the learning process in schools.

\section{REFERENCE}

Arwildayanto, A. S., \& Sumar, W. T. (2018). Analisis Kebijakan Pendidikan Kajian Teoritis, Eksploratif, Dan Aplikatif. Bandung: CV. Cindekia Press.

Aziz, A. (2017). Komunikasi pendidik dan peserta didik dalam pendidikan islam. Jurnal Mediakita: Jurnal Komunikasi dan Penyiaran Islam, 1 (2).https://doi.org/10.30762/ mediakita.v1i2.365

Barnawi, \& Arifin, M. (2012). Manajemen Sarana \& Prasarana Sekolah. Yogyakarta: Ar-Ruzz
Media.

Buchari, A. (2018). Peran Guru Dalam Pengelolaan Pembelajaran. Jurnal Ilmiah Iqra', 12(2), 106124. doi: 10.30984/jii.v12i2.897

Darmadi, H. (2011). Metode Penelitian Pendidikan. Bandung: Alfabeta.

Fakhrurrazi. (2018). Hakikat Pembelajaran yang Efektif. At-Tafkir 11(1): 85. https:// doi.org/10.32505/at.v11i1.529

Ikawati, M. P. D., \& Prihantini, M. (2016). Upaya meningkatkan konsentrasi belajar siswa KMS (Kartu Menuju Sejahtera) menggunakan konseling kelompok bagi siswa. Jurnal Psikopedagogia, 5 . https://doi.org/10.12928/ psikopedagogia.v4i2.4484

Suwardi, I., \& Farnisa, R. (2018). Hubungan Peran Guru Dalam Proses Pembelajaran Terhadap Prestasi Belajar Siswa. Jurnal Gentala Pendidikan Dasar, 3(2), 181-202.

Darimi, I. (2016). Diagnosis kesulitan belajar siswa dalam pembelajaran aktif di sekolah. JURNAL EDUKASI: Jurnal Bimbingan Konseling, 2(1), 30-43. https://doi.org/10.22373/je.v2i1.689

Junaedi, A. (2016). Survei Tingkat Kemajuan Pendidikan Jasmani, Olahraga, Dan Kesehatan Di Sma, Smk, Dan Ma Negeri Se-Kabupaten Gresik. Jurnal Pendidikan Olahraga dan Kesehatan, 3(3).

Nurizzati, Y. (2018). Dampak Penggunaan Teknologi dan Informasi dan Komunikasi terhadap Perilaku Sosial Siswa di MAN 2 Kuningan. Edueksos: Jurnal Pendidikan Sosial \& Ekonomi,7(2). https:// doi.org/10.24235/edueksos.v7i2.3370

Komalasari, K. (2010). Pembelajarn Kontekstual: Konsep dan Aplikasi. Bandung: Refika Aditama.

Muhammad, M., Gani, H., \& Arifin, A. (2017). Pengaruh Faktor Sosial Ekonomi Orang Tua Terhadap Minat Melanjutkan Pendidikan Anak di Desa Wunse Jaya Kecamatan Wawonii Tenggara Kabupaten Konawe Kepulauan. Al-Ta'dib, 10(1), 163-180.

Nasrudin, N., \& Maryadi, M. (2019). Manajemen Sarana dan Prasarana Pendidikan dalam Pembelajaran di SD. Manajemen Pendidikan, 13 (2), 15-23.

Nurcholiq, M. (2018). Supervisi Klinis. Journal EVALUASI, 1(1), 1-25.

Musa, M. I. (2015). Pelayanan Pendidikan yang Berkualitas di Era Global dalam Mengembangkan Potensi Peserta Didik secara Maksi- 
mal. Jurnal Pesona Dasar, 1(4): 52-65.

Pane, A., \& Dasopang, M. D. (2017). Belajar dan pembelajaran. Fitrah: Jurnal Kajian Ilmu-Ilmu Keislaman, 3(2), 333-352. https:// doi.org/10.24952/fitrah.v3i2.945.

Rismawan, E. (2015). Pengaruh Supervisi Kepala Sekolah dan Motivasi Berprestasi Guru Terhadap Kinerja Mengajar Guru. Jurnal Administrasi Pendidikan, 22(1) 114-132.

Romadhoni, E., Wiharna, O., \& Mubarok, I. (2017). Pengaruh Motivasi Belajar terhadap Hasil Belajar Peserta Didik pada Mata Pelajaran Gambar Teknik. Journal of Mechanical Engineering Education, 6(2), 228-234. https:// doi.org/10.17509/jmee.v6i2.21799

Sugiarto, B. G. (2015). Pengaruh Distribusi Alokasi Waktu Pembelajaran Pendidikan Jasmani Terhadap Perilaku Hidup Aktif Dan Kebugaran Jasmani Siswa Sekolah Dasar. Motion: Jurnal Riset Physical Education, 6(1), 93-108.

Sugiyono, D. (2010). Metode penelitian kuantitatif dan $R \& D$. Bandung: Alfabeta.

Sugiyono. (2018). Metode Penelitian Kuantitatif (1st ed.). Bandung: Alfabeta.

Sunhaji, S. (2014). Konsep Manajemen Kelas Dan Implikasinya Dalam Pembelajaran. Jurnal Kependidikan, 2(2), 30-46. https:// doi.org/10.24090/jk.v2i2.551

Fikri, A. (2018). Studi Tentang Tingkat Kesegaran Jasmani Mahasiswa Penjaskes STKIP PGRI Lubuklinggau. Gelanggang Olahraga: Jurnal Pendidikan Jasmani Dan Olahraga, 1(2), 7483. https://doi.org/https://doi.org/10.31539/ jpjo.v1i2.136

Supriyo, S. (2015). Pengaruh Buku Teks Dan Cetak Terhadap Hasil Belajar Di Sma N I Marga Tiga Kabupaten Lampung Timur Pada Kelas Xii. Ips Tahun Pelajaran 2013/2014. Promosi (Jurnal Pendidikan Ekonomi) 3(1): 83-92. https://doi.org/10.24127/ja.v3i1.145.

Syafi'i, A., Marfiyanto, T., \& Rodiyah, S. K. (2018). Studi Tentang Prestasi Belajar Siswa Dalam Berbagai Aspek Dan Faktor Yang Mempengaruhi. Jurnal Komunikasi Pendidikan, 2(2), 115-123. https://doi.org/10.32585/ jkp.v2i2.114.

Wisman, Y. (2017). Komunikasi efektif dalam dunia pendidikan. Jurnal Nomosleca, 3(2): 646-654. https://doi.org/10.26905/nomosleca.v3i2.2039.

Yulianti, M. (2016). Pengaruh Metode Pembelajaran Demonstrasi terhadap Keterampilan bermain Bola Voli Siswa di SMPN 1 Batu Ber- surat. Primary: Jurnal Pendidikan Guru Sekolah Dasar, 5(1): 78-82. https:// doi.org/10.33578/jpfkip.v5i1.3681 